\title{
Intraoperative images of gastric band complications
}

\author{
Sofia Costa Corado, José Neves
}

Department of Surgery, Centro Hospitalar e Universitário de Lisboa Central, Lisboa, Portugal

\section{Correspondence to}

Dr Sofia Costa Corado, sofiacorado@gmail.com

Accepted 12 December 2018

\section{DESCRIPTION}

A 54-year-old man was admitted to the emergency department for upper intestinal bleeding which was diagnosed during an upper endoscopy.

Seventeen months before, the patient had a laparoscopic gastric band procedure, with a body mass index of $51 \mathrm{~kg} / \mathrm{m}^{2}$ and had lost $50 \mathrm{~kg}$ since then. He only remembered having filled the band once, 1 month after its placement.

In the weeks preceding the endoscopy, he began to feel epigastric pain that did not improve or worsen with meals, but required painkillers for comfort. For this reason, he underwent an upper endoscopy. This examination diagnosed gastroduodenal bleeding due to a migration of the band, however no endoscopic control could be done. The patient was transferred to our hospital's emergency department in hypovolaemic shock and was not responsive to resuscitative efforts. He was taken to the operating room for emergency surgery.

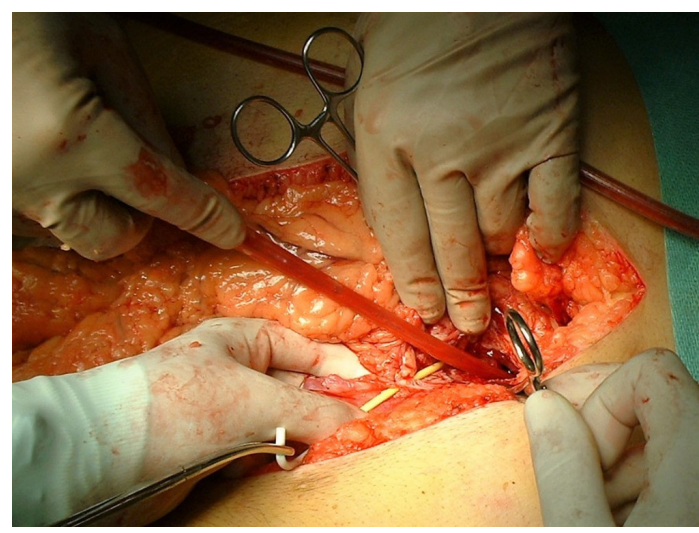

Figure 1 Gastroduodenotomy and removal of the gastric band tubing after division near the abdominal wall.

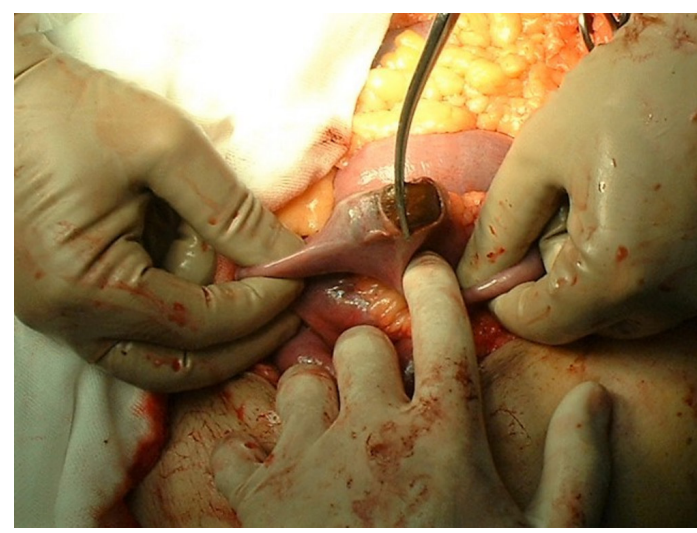

Figure 2 Identification of the migrated gastric band in the jejunum.

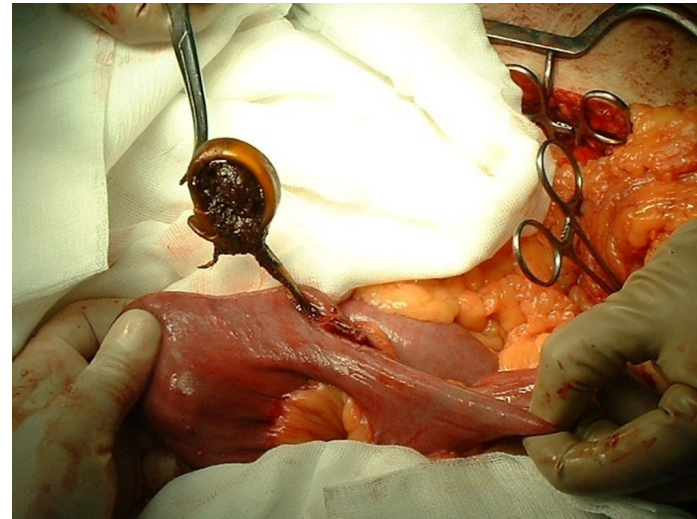

Figure 3 Removal of the migrated gastric band through the jejunotomy.

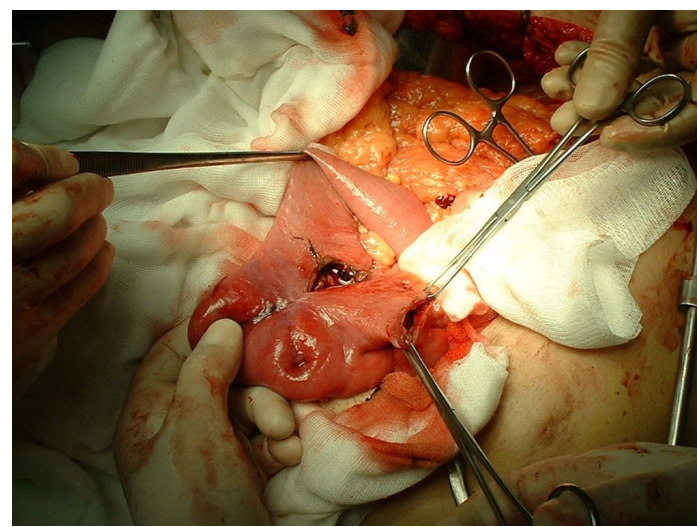

Figure 4 Identification of an enteroenteric fistula caused by the migration of the band.

A laparotomy revealed a distended stomach and blood in the small bowel. A gastroduodenotomy was performed and revealed profuse bleeding (figure 1) due to the laceration of the gastroduodenal artery by the outstretched gastric band connecting tube, and migration of the band itself into the jejunum (figure 2).

After controlling the bleeding, the attempts to remove the band through the gastroduodenotomy proved unsuccessful. A jejunotomy was performed at the site of the band to remove it (figure 3 ) and revealed the presence of an enteroenteric fistula (figure 4) secondary to erosion which was caused by the band.

Gastroduodenotomy was closed by performing a Heineke-Mikulicz pyloroplasty, and jejunotomy sites were closed with sutures. No drains were placed. The patient presented with an uneventful recovery. $\mathrm{He}$ started to drink clear liquids by the fourth day and progressed to diet as tolerated.

We present this case as an example of possible gastric band complications. Although potentially 
life-threatening, erosion and intragastric band migration are rare late complications and can present as gastrointestinal bleeding. ${ }^{1-3}$

Physicians working in emergency departments should be aware of possible band-related complications in this group of patients. $^{1}$

\section{Learning points}

Serious and life-threatening complications can derive from gastric band procedures.

- Presentation can be as severe as unresponsive hypovolaemic shock.

- Migration of the band, gastrointestinal bleeding and fistulation can happen simultaneously.
Contributors SCC is responsible for conception and design. JN is responsible for the images displayed and revision of content.

Funding The authors have not declared a specific grant for this research from any funding agency in the public, commercial or not-for-profit sectors.

Competing interests None declared.

Patient consent Obtained.

Provenance and peer review Not commissioned; externally peer reviewed.

\section{REFERENCES}

1 Creedon L, Leeder P, Awan A. Laparoscopic adjustable gastric band erosion and migration into the proximal jejunum. Surg Obes Relat Dis 2014;10:e19-21.

2 Allen JW. Laparoscopic gastric band complications. Med Clin North Am 2007:91:485-97.

3 Contival N, Menahem B, Gautier T, et al. Guiding the non-bariatric surgeon through complications of bariatric surgery. J Visc Surg 2018;155:27-40.

Copyright 2018 BMJ Publishing Group. All rights reserved. For permission to reuse any of this content visit https://www.bmj.com/company/products-services/rights-and-licensing/permissions/

BMJ Case Report Fellows may re-use this article for personal use and teaching without any further permission.

Become a Fellow of BMJ Case Reports today and you can:

- Submit as many cases as you like

- Enjoy fast sympathetic peer review and rapid publication of accepted articles

- Access all the published articles

Re-use any of the published material for personal use and teaching without further permission

For information on Institutional Fellowships contact consortiasales@bmjgroup.com

Visit casereports.bmj.com for more articles like this and to become a Fellow 